\title{
PENGARUH MOTIVASI DAN DISIPLIN KERJA TERHADAP KINERJA PEGAWAI NEGERI SIPIL PADA KANTOR KELURAHAN DI WILAYAH KECAMATAN MANTIKULORE KOTA PALU
}

\author{
SRI WAYATI NINGSI \\ LINA MAHARDIANA \\ RISNAWATI \\ Program Studi S1 Manajemen, Fakultas Ekonomi, Universitas Tadulako \\ Email: sriwayatiningsi12@gmail.com
}

\begin{abstract}
This study aims to determine and analyze the influence of Motivation and Discipline Work simultaneously or partially affect the performance of employees at the village office in the District Mantikulore Palu. This study uses quantitative research which is a research that aims to explain the relationship between two or more variables with a sample of 99 employees and data analysis techniques used are multiple linear regression. The results of hypothesis analysis and testing can be concluded: (1) based on regression test results obtained sig. F of $0.00<0.05$. This means that the variables of Motivation and Work Discipline simultaneously have a significant effect on employee performance variable. (2) based on the regression test results obtained motivation variable has significance level t sig. $0.033<\alpha 0.05$. It means that partially motivation variable has significant effect to employee performance variable. (3) based on regression test results obtained by motivation variable has significance level $t$ sig. 0,000> $\alpha$ 0.05. It means that partially variable of Work Discipline have significant effect to employee performance variable.
\end{abstract}

Keywords: motivation, work discipline, performance

\begin{abstract}
Abstrak
Penelitian ini bertujuan untuk mengetahui dan menganalisis pengaruh Motivasi dan Disiplin Kerja secara simultan maupun parsial berpengaruh terhadap kinerja pegawai pada kantor kelurahan di Wilayah Kecamatan Mantikulore Kota Palu. Penelitian ini menggunakan penelitian kuantitatif yang merupakan penelitian yang bertujuan untuk menjelaskan hubungan antara dua variabel atau lebih dengan sampel 99 pegawai dan teknik analisis data yang digunakan adalah regresi linear berganda. Hasil analisis dan pengujian hipotesis dapat disimpulkan: (1) Berdasarkan hasil uji regresi diperoleh sig. F sebesar $0,00<0,05$. Hal ini bermakna bahwa variabel Motivasi dan Disiplin Kerja secara simultan berpengaruh signifikan terhadap variabel kinerja pegawai. (2) Berdasarkan hasil uji regresi diperoleh variabel Motivasi memiliki tingkat signifikasi t sig. $0,033<\alpha 0,05$. Hal ini bermakna bahwa secara parsial variabel Motivasi berpengaruh signifikan terhadap variabel kinerja pegawai. (3) Berdasarkan hasil uji regresi diperoleh variabel Motivasi memiliki tingkat signifikasi t sig. 0,000> $\alpha$ 0,05 . Hal ini bermakna bahwa secara parsial variabel Disiplin Kerja berpengaruh signifikan terhadap variabel kinerja pegawai.
\end{abstract}

Kata kunci: motivasi, disiplin kerja, kinerja

\section{PENDAhULUAN}

Kedudukan dan peranan Pegawai Negeri Sipil di Indonesia dirasakan semakin penting. Oleh karena itu, penyelenggaraan pemerintahan memerlukan orang-orang yang selalu mampu untuk melaksanakan tugas dan tanggung jawabnya untuk berpartisipasi dalam kegiatan pemerintah, pembangunan dan kemasyarakatan secara berdaya guna dan berhasil guna. Berdasarkan aspirasi masyarakat sesuai dengan peraturan perundang-undangan nomor 32 tahun 2004, pemberian otonomi kepada daerah dimaksudkan untuk meningkatkan daya guna dan hasil guna penyelenggaraan pemerintah di daerah, terutama dalam pelaksanaan pembangunan dan pelayanan terhadap masyarakat serta untuk meningkatkan pembinaan kestabilan politik dan kesatuan bangsa. Konsekuensi dari hal tersebut pemerintah kelurahan dituntut memiliki kemampuan yang semakin tinggi untuk menjawab tantangan 
Ningsi, S.W.

tugas yang semakin berat. Karena itu, diperlukan upaya untuk meningkatkan kemampuan pemerintah kelurahan baik kemampuan dalam mengambil inisiatif, prakarsa, perencanaan, pelaksanaan maupun pengawasan, sehingga diperoleh kinerja pemerintah yang baik. Pembentukan kelurahan ditujukan untuk meningkatkan kemampuan penyelenggaraan pemerintahan kelurahan dalam hal pemberian pelayanan publik kepada masyarakat. Kecamatan Mantikulore sendiri merupakan kecamatan hasil pemekaran di Kota Palu sesuai dengan Peraturan Daerah nomor 4 Tahun 2012 Tentang Pembentukan Kecamatan. Kecamatan Mantikulore terdiri dari 8 (delapan) kelurahan.

Keberhasilan suatu organisasi sangat tergantung pada kualitas SDM dan kemampuan dari pemimpin dalam menggerakan dan mendorong bawahan untuk meningkatkan keterampilan dan kemampuannya untuk mencapai tujuan yang telah ditetapkan. Menurut Mathis dan Jackson dalam Bangun (2011:115) motivasi merupakan hasrat di dalam diri seseorang menyebabkan orang tersebut melakukan tindakan. Seseorang melakukan tindakan untuk sesuatu hal mencapai tujuan. Berdasarkan hasil wawancara yang dilakukan dengan Pegawai pada Kantor Kelurahan di Wilayah Kecamatan Mantikulore Kota Palu ditemukan bahwa, pegawai di kelurahan sangat kurang mendapatkan motivasi dan pengawasan dari kepala kelurahannya sendiri karena jarangnya kepala kelurahan yang berada di kantor karena sedang mengikuti rapat atau urusan pekerjaan lain. Hal ini tentunya akan berdampak pada terhambatnya komunikasi (hubungan sosial) pimpinan kepada pegawainya serta penurunan semangat kerja pada diri pegawai, terlihat dari tidak adanya inisiatif bekerja dalam diri pegawai terlihat dari sikap pegawai yang pasif terhadap tugas dan tanggungjawabnya, serta banyaknya pegawai yang terlihat santai pada jam kerja ketika tidak adanya pimpinan di kantor.

Sebuah instansi sangat perlu adanya penerapan disiplin kerja pada pegawai karena apabila terjadi kurangnya kedisiplinan dari pegawai maka kinerja yang dihasilkan pun menurun yang dimana hal tersebut akan memberi dampak pada kinerja instansi tersebut. Hasibuan (2013:193) mengemukakan bahwa semakin baik disiplin karyawan, semakin tinggi prestasi kerja yang dapat dicapainya. Disiplin yang baik mencerminkan besarnya tanggung jawab seseorang terhadap tugas-tugas yang diberikan kepadanya. Kinerja merupakan hasil kerja secara kualitas dan kuantitas yang dicapai oleh seseorang pegawai dalam melaksanakan tugasnya sesuai dengan tanggung jawab yang diberikan kepadanya. Mangkunegara (2009:67).

Peran kepala lurah dalam sebuah instansi kelurahan merupakan peran yang sangat penting untuk meningkatkan kinerja para pegawai. Berdasarkan uraian diatas dan permasalahan yang ada maka penulis tertarik untuk melakukan penelitian dengan judul "Pengaruh Motivasi dan Disiplin Kerja Terhadap Kinerja Pegawai Negeri Sipil Pada Kantor Kelurahan Di Wilayah Kecamatan Mantikulore Kota Palu".

\section{KAJIAN LITERATUR DAN PENGEMBANGAN HIPOTESIS}

\section{Teori Motivasi}

Pemberian motivasi oleh pimpinan kepada bawahannya diharapkan dapat meningkatkan kinerja pegawai terhadap organisasi. Tindakan motivasi adalah suatu tindakan memotivasi dari pimpinan untuk pegawai atau anggota dalam organisasi untuk terus memberikan kinerja terbaik yang melalui komunikasi yang intens, mendorong pegawai melalui pengakuan kepada pegawai, dan mendesak bawahan untuk meningkatkan kinerjanya.

Rivai (2003:455) menyatakan bahwa motivasi adalah serangkaian sikap dan nilai-nilai yang mempengaruhi individu untuk mencapai hal yang spesifik sesuai dengan tujuan individu. Sikap dan nilai tersebut merupakan suatu yang invisible yang memberikan kekuatan untuk mendorong individu bertingkah laku dalam mencapai tujuan. Siagian (2004:138) mengemukakan bahwa Motivasi adalah daya pendorong yang mengakibatkan seseorang anggota organisasi mau dan rela untuk mengerahkan kemampuan dalam bentuk keahlian atau keterampilan, tenaga dan waktunya untuk menyelenggarakan 
berbagai kegiatan yang menjadi tanggung jawabnya dan menunaikan kewajibannya, dalam rangka pencapaian tujuan dan berbagai sasaran organisasi yang telah ditentukan sebelumnya.

\section{Indikator Motivasi}

Indikator variabel motivasi menggunakan teori dari Clayton Alderfer dalam Bangun (2011:128), yaitu:

1. Kebutuhan akan eksistensi (Existence needs);

Yaitu kebutuhan yang berhubungan dengan kebutuhan dasar termasuk di dalamnya kebutuhan fisiologi dan kebutuhan keamanan dan keselamatan dari Maslow.

2. Kebutuhan akan hubungan (Related needs);

Kebutuhan ini menekankan akan pentingnya hubungan antar-individu (interpersonal relationship) dan juga bermasyarakat (social relationship). Kebutuhan ini berhubungan dengan kebutuhan sosial dan kebutuhan status dari Maslow.

3. Kebutuhan akan pertumbuhan (growth needs);

Yaitu keinginan intrinsik dalam diri seseorang untuk maju atau meningkatkan kemampuan pribadinya.

\section{Teori Disiplin Kerja}

Kedisiplinan merupakan fungsi operatif MSDM yang terpenting. Semakin baik disiplin karyawan pada sebuah perusahaan, semakin tinggi prestasi kerja yang dapat dicapai. Sebaliknya, tanpa disiplin karyawan yang baik, sulit bagi sebuah perusahaan mencapai hasil yang optimal. Menurut Singodimedjo dalam Sutrisno (2009:86) disiplin adalah sikap ketersediaan dan kerelaan seseorang untuk mematuhi dan menaati norma-norma peraturan yang berlaku disekitarnya.

Disiplin karyawan yang baik akan mempercepat tujuan perusahaan, sedangkan disiplin yang merosot akan menjadi penghalang dan memperlambat pencapaian tujuan perusahaan. Menurut Sutrisno (2009:86) disiplin menunjukan suatu kondisi atau sikap hormat yang ada pada diri karyawan terhadap peraturan dan ketetapan perusahaan.

\section{Indikator Disiplin Kerja}

Indikator variabel disiplin kerja menggunakan teori dari Soetrisno PH (1992:93-94), yaitu:

1. Disiplin waktu

berarti bersikap faktual terhadap waktu yang ditetapkan termasuk jam mulai kerja, jam istirahat dan jam pulang kantor dan jam mulai serta penutupan rapat-seminar dan lain-lain.

2. Disiplin moral

adalah disiplin yang keluar dari hati nurani untuk berusaha menepati atau menyelesaikan suatu pekerjaan.

3. Disiplin administratif

Disiplin administratif adalah disiplin untuk mengerjakan (dan atau tidak mengerjakan) seperti yang tertera dalam aturan atau kaidah yang ditetapkan sebelumnya. Kaidah tersebut dapat bersifat tertulis, tidak tertulis, dapat berupa suatu norrma hukum, norma kesusilaan, peraturan kepegawaian dan lain-lain.

\section{Teori Kinerja}

Kinerja merupakan suatu fungsi dari motivasi dan kemampuan untuk menyelesaikan tugas atau pekerjaan seseorang sepatutnya memiliki derajat ketersediaan dan tingkat kemampuan tertentu. Menurut Rivai (2004:309) Kinerja merupakan perilaku nyata yang ditampilkan setiap orang sebagai prestasi kerja yang dihasilkan oleh karyawan sesuai dengan perannya dalam perusahaan.

Kinerja menurut Wibowo (2007) berasal dari pengertian "performance" yang memberikan pengertian sebagai hasil kerja atau prestasi kerja. Robert L. Mathis dan Jhon H. Jackson dalam Fahmi (2010:65) bahwa penilaian kinerja merupakan proses mengevaluasi seberapa baik karyawan 
Ningsi, S.W.

mengerjakan pekerjaan mereka ketika dibandingkan dengan satu set standar, dan kemudian mengomunikasikan informasi tersebut.

\section{Indikator Kinerja}

Indikator variabel kinerja menggunakan teori dari Dharma dalam bukunya Manajemen Supervisi (2003:355), yaitu:

1. Kualitas hasil kerja, yaitu berhubungan dengan baik tidaknya mutu dari hasil kerja pegawai.

2. Kuantitas hasil kerja, yaitu berhubungan dengan jumlah yang dihasilkan dan jumlah yang harus diselesaikan atau dicapai oleh pegawai.

3. Ketepatan waktu penyelesaian pekerjaan, yaitu berhubungan dengan ketepatan waktu penyelesaian pekerjaan yang dilakukan oleh pegawai.

\section{Kerangka Pemikiran}

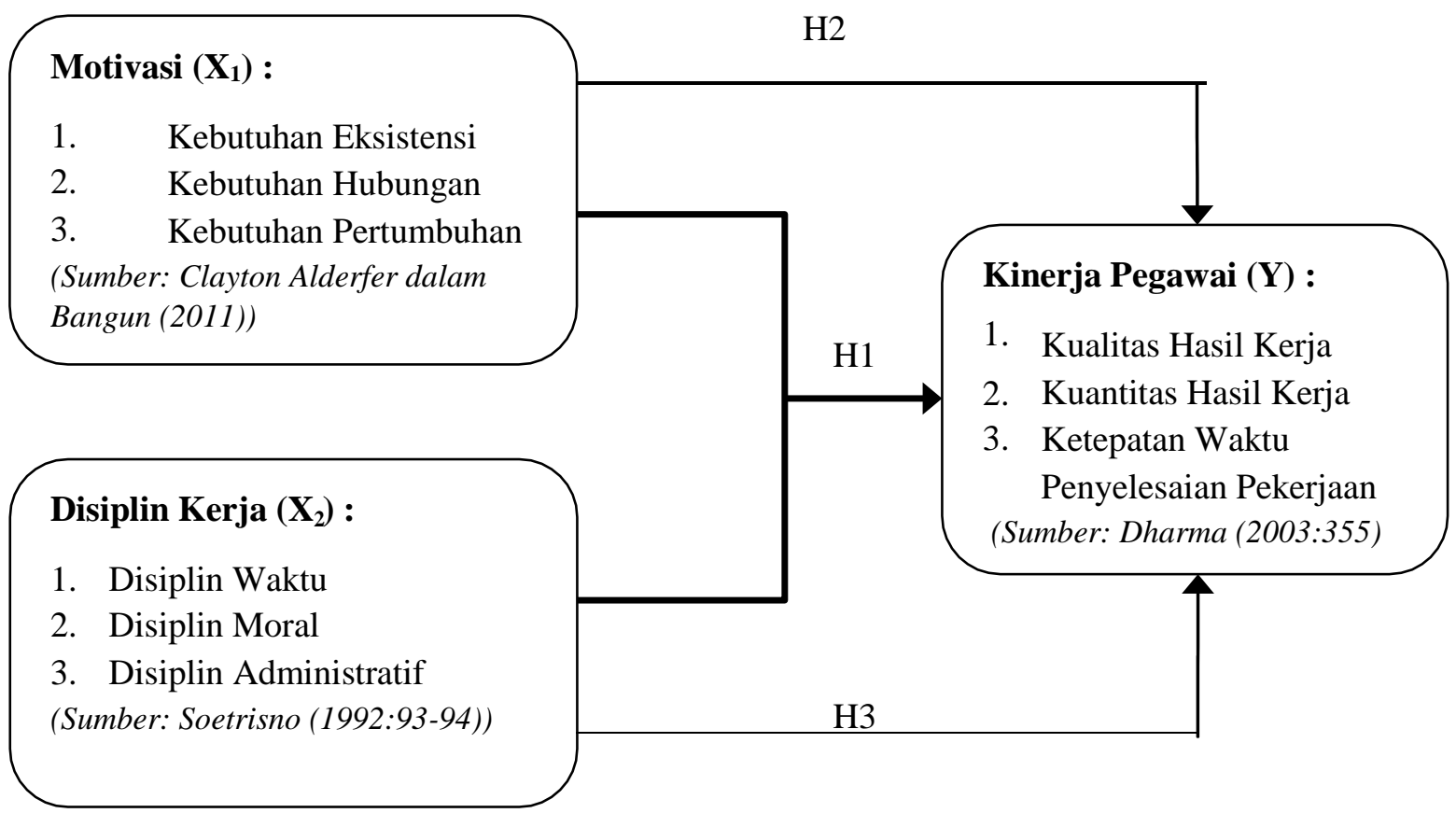

Gambar 1.

Kerangka Pemikiran

Keterangan:

Garis pengaruh secara serempak

Garis pengaruh secara parsial

\section{Hipotesis}

1. $\mathrm{H}_{1}$ : Variabel motivasi dan disiplin kerja secara simultan mempunyai pengaruh terhadap kinerja pegawai negeri sipil pada Kantor Kelurahan di wilayah Kecamatan Mantikulore Kota Palu.

2. $\mathrm{H}_{2}$ : Variabel motivasi secara parsial mempunyai pengaruh terhadap kinerja pegawai negeri sipil pada Kantor Kelurahan di wilayah Kecamatan Mantikulore Kota Palu.

3. $\mathrm{H}_{3}$ : Variabel disiplin kerja secara parsial mempunyai pengaruh terhadap kinerja pegawai negeri sipil pada Kantor Kelurahan di wilayah Kecamatan Mantikulore Kota Palu.

\section{METODE PENELITIAN}




\section{Jenis Penelitian}

Jenis Penelitian ini adalah penelitian assosiatif. Dasar pertimbangan pemilihan ini karena penelitian ini bertujuan untuk meihat pengaruh antara dua variabel atau lebih. Menurut Sugiyono (2011) penelitian assosiatif yaitu penelitian yang dilakukan untuk megetahui hubungan antara dua variabel. Penelitian tersebut, akan menggambarkan seberapa besar pengaruh variabel independen (Motivasi dan Disiplin Kerja) terhadap variabel dependen (Kinerja Pegawai).

\section{Lokasi Penelitian}

Lokasi penelitian ini dilakukan pada Kantor Kelurahan di wilayah Kecamatan Mantikulore Kota Palu, alasan memilih lokasi penelitian ini karena adanya fenomena yang terkait dengan variabel motivasi dan disiplin dengan kinerja pegawai negeri sipil pada kantor kelurahan di kecamatan mantikulore kota palu.

\section{Teknik Pengumpulan Data}

\section{Observasi}

Teknik ini menuntut adanya pengamatan dari peneliti baik secara langsung maupun tidak langsung terhadap objek penelitian, Noor (2011:140).

\section{Wawancara}

Teknik pengumpulan data yang dilakukan secara langsung dengan yang diwawancarai tetapi dapat juga diberikan daftar pertanyaan dahulu untuk dijawab pada kesempatan lain, Noor (2011:138).

3. Kuesioner (angket)

Teknik pengumpulan data yang berupa daftar pertanyaan atau pernyataan tentang topik tertentu yang yang diberikan kepada subyek, baik secara individual atau kelompok, untuk mendapatkan informasi tertentu, seperti preferensi, keyakinan, minat dan perilaku. Untuk mendapatkan informasi dengan subyek, tetapi cukup dengan mengajukan pertanyaan atau pernyataan secara tertulis untuk mendapatkan respon, Hadjar dalam Taniredja dan Mustafidah (2014:44).

\section{Dokumentasi}

Dokumentasi merupakan sumber data sekunder, dimana secara detail bahan dokumentar terbagi beberapa macam, yaitu autobiografi, surat pribadi, buku atau catatan harian, memorial, klipping, dokumen pemerintah atau swasta, data di server dan data yang tersimpan di web site. Noor (2011:141).

\section{Teknik Pengambilan Sampel}

Teknik penarikan sampel yang digunakan dalam penelitian ini, yaitu menggunakan teknik penarikan sampling jenuh, Sugiyono (2014:122-123) sampling jenuh adalah teknik penentuan sampel bila semua anggota populasi digunakan sebagai sampel. Istilah lain sampel jenuh adalah sensus, dimana semua anggota populasi dijadikan sampel.

\section{Metode Analisis Data}

\section{Analisis Regresi Linear Berganda}

Fuad Masud (2004) secara umum analisis regresi ialah analisis yang dilakukan untuk mengetahui pengaruh hubungan (asosiasi) antara dua variabel yakni variabel X (independen) dan variabel $\mathrm{Y}$ (dependen). Menurut Sugiyono (2014:277) analisis regresi linear berganda digunakan oleh peneliti bila peneliti bermaksud meramalkan bagaimana keadaan (naik turunnya) variabel dependen (kriterium), bila dua atau lebih variabel independen sebagai faktor prediktor dimanipulasi (di naik turunkan nilainya). Persamaan regresi linear berganda dalam penelitian ini adalah:

$$
\mathbf{Y}=\mathbf{a}+\mathbf{b}_{1} \mathbf{X}_{1}+\mathbf{b}_{2} \mathbf{X}_{2}
$$


Keterangan:

$Y \quad=$ Kinerjapegawai

$a \quad=$ Konstanta

$b_{1} \quad=$ Koefisien regresi motivasi

$b_{2} \quad=$ Koefisien regresi disiplin kerja

$X_{1} \quad=$ Motivasi

$X_{2} \quad=$ Disiplin Kerja

\section{HASIL DAN PEMBAHASAN}

Analisis regresi linear berganda digunakan dengan tujuan untuk mengetahui ada tidaknya pengaruh variabel independen terhadap variabel dependen. Berkaitan dengan penelitian ini alat analisis statistik regresi linear berganda yang digunakan untuk mengetahui pengaruh Motivasi $\left(\mathrm{X}_{1}\right)$ dan Disiplin Kerja $\left(\mathrm{X}_{2}\right)$ terhadap Kinerja $(\mathrm{Y})$ pegawai Kantor Kelurahan di Wilayah Kecamatan Mantikulore Kota Palu. Sesuai hasil analisis regresi linear berganda dengan menggunakan bantuan program SPSS For Windows Release 16.0, dengan hasil penelitian dari 99 responden, diperoleh hasil perhitungan sebagai berikut:

Tabel 1.

Hasil Analisis Regresi Linear Berganda

\begin{tabular}{|c|c|c|c|c|}
\hline \multicolumn{5}{|c|}{ Dependen Variabel Y = Kinerja Pegawai } \\
\hline Variabel & $\begin{array}{c}\text { Koefisien } \\
\text { Regresi }\end{array}$ & $\begin{array}{l}\text { Standar } \\
\text { Error }\end{array}$ & $\mathrm{T}$ & Sig \\
\hline Constanta & 0.117 & 0.499 & 0.234 & 0.815 \\
\hline X1=Motivasi & 0.165 & 0.076 & 2.165 & 0.033 \\
\hline X2=Disiplin Kerja & 0.706 & 0.095 & 7.432 & 0.000 \\
\hline $\mathrm{R}$ & $=0.616$ & & & \\
\hline R-Square & $=0.380$ & & & \\
\hline F Statistik & $=29.369$ & & & \\
\hline Sig F & $=0.000<0.05$ & & & \\
\hline
\end{tabular}

Sumber: Hasil Regresi

Berdasarkan nilai dari tabel.1 di atas, maka persamaan regresi linear berganda dapat dirumuskan sebagai berikut:

$$
Y=0.117+0.165 X_{1}+0.706 X_{2}
$$

Berdasarkan persamaan tersebut maka dapat dinyatakan bahwa variabel independen $\left(\mathrm{X}_{1}\right.$ dan $\left.\mathrm{X}_{2}\right)$ memberi pengaruh positif terhadap variabel dependen $(\mathrm{Y})$.

1. Nilai konstanta sebesar 0,117 berarti kinerja pegawai pada Kantor Kelurahan di Wilayah Kecamatan Mantikulore Kota Palu sebelum adanya variabel independen adalah sebesar 0,117.

2. Motivasi $\left(\mathrm{X}_{1}\right)$ dengan nilai koefisien regresi 0,165 , hal ini berarti terjadi pengaruh positif antara motivasi dan kinerja pegawai. Hal ini menyatakan bahwa jika motivasi di tingkatkan maka akan meningkat pula kinerja pegawai pada Kantor Kelurahan di Wilayah Kecamatan Mantikulore Kota Palu

3. Disiplin Kerja $\left(\mathrm{X}_{2}\right)$ dengan koefisien regresi 0,706 , hal ini berarti terjadi pengaruh positif antara disiplin kerja dan kinerja pegawai. Hal ini menyatakan bahwa jika disiplin kerja pegawai di tingkatkan maka akan meningkat pula kinerja pegawai pada Kantor Kelurahan di Wilayah Kecamatan Mantikulore Kota Palu.

\section{Uji F}


Uji $\mathrm{F}$ bertujuan untuk mengetahui apakah variabel independen yakni motivasi $\left(\mathrm{X}_{1}\right)$ dan disiplin kerja $\left(\mathrm{X}_{2}\right)$ yang diteliti memiliki pengaruh secara simultan terhadap variabel dependen yakni kinerja (Y) pegawai pada Kantor Kelurahan di Wilayah Kecamatan Mantikulore Kota Palu. Berdasarkan Tabel 1. terlihat hasil perhitungan diperoleh $\mathrm{F}_{\text {hitung }}=29,369$ pada taraf nyata $\alpha=0,05$ dan nilai signifikansi $\mathrm{F}=0,000<0,05$. Kesimpulannya adalah bahwa variabel independen yakni motivasi $\left(\mathrm{X}_{1}\right)$ dan disiplin kerja $\left(\mathrm{X}_{2}\right)$ secara simultan berpengaruh signifikan terhadap variabel dependen yakni kinerja (Y) pegawai pada Kantor Kelurahan di Wilayah Kecamatan Mantikulore Kota Palu. Berdasarkan hasil tersebut dapat disimpulkan bahwa hipotesis pertama terbukti $\left(\mathrm{H}_{0}\right.$ ditolak dan $\mathrm{H}_{\mathrm{a}}$ diterima).

\section{Uji t}

Uji t digunakan untuk mengetahui apakah variabel independen yakni motivasi $\left(\mathrm{X}_{1}\right)$ dan disiplin kerja $\left(\mathrm{X}_{2}\right)$ yang diteliti memiliki pengaruh secara parsial terhadap variabel dependen yakni kinerja $(\mathrm{Y})$ pegawai pada Kantor Kelurahan di Wilayah Kecamatan Mantikulore Kota Palu. Adapun hasil uji hipotesis secara parsial dapat dilihat sebagai sebagai berikut:

\section{Motivasi $\left(\mathrm{X}_{1}\right)$}

Hasil pengujian pada variabel motivasi di peroleh tingkat signifikansi $(0,033)<\alpha(0,05)$. Hal ini bermakna secara parsial variabel motivasi $\left(\mathrm{X}_{1}\right)$ berpengaruh signifikan terhadap variabel kinerja (Y) pegawai pada Kantor Kelurahan di Wilayah Kecamatan Mantikulore Kota Palu. Berdasarkan hasil di atas, maka hipotesis kedua untuk variabel motivasi $\left(\mathrm{X}_{1}\right)$ dalam penelitian yang telah dilakukan, terbukti ( $\mathrm{H}_{0}$ ditolak $\mathrm{H}_{\mathrm{a}}$ diterima).

2. Disiplin Kerja $\left(\mathrm{X}_{2}\right)$

Hasil pengujian pada variabel disiplin kerja di peroleh tingkat signifikansi $(0,000)<\alpha(0,05)$. Hal ini bermakna secara parsial variabel disiplin kerja $\left(\mathrm{X}_{2}\right)$ berpengaruh signifikan terhadap variabel kinerja (Y) pegawai pada Kantor Kelurahan di Wilayah Kecamatan Mantikulore Kota Palu. Berdasarkan hasil di atas, maka hipotesis ketiga untuk variabel disiplin kerja $\left(\mathrm{X}_{2}\right)$ dalam penelitian yang telah dilakukan, terbukti $\left(\mathrm{H}_{0}\right.$ ditolak $\mathrm{H}_{\mathrm{a}}$ diterima $)$.

\section{Pembahasan}

\section{Pengaruh Motivasi $\left(X_{1}\right)$ dan Disiplin Kerja $\left(X_{2}\right)$ Terhadap Kinerja (Y) Pegawai Pada Kantor Kelurahan Di Wilayah Kecamatan Mantikulore Kota Palu.}

Berdasarkan pada hasil pengujian hipotesis pertama yaitu Uji-F menunjukkan bahwa pada hipotesis pertama $\left(\mathrm{H}_{1}\right)$ yang menyatakan variabel motivasi dan disiplin kerja secara simultan mempunyai pengaruh signifikan terhadap kinerja pegawai pada Kantor Kelurahan di wilayah Kecamatan Mantikulore Kota Palu. Hal ini mengindikasikan bahwa kedua variabel independen tersebut memiliki pengaruh terhadap peningkatan kinerja pegawai. Motivasi merupakan hal yang memengaruhi dari segi keinginan dalam diri pegawai untuk melakukan kegiatan/pekerjaan guna meningkatkan kinerjanya sehingga berpengaruh pada pencapaian tujuan, sedangkan disiplin kerja memengaruhi dari segi sikap taat dan patuh dalam melaksanakan tugas dan prosedur yang telah di tetapkan guna untuk mencapai tujuan.

Hal ini menunjukkan bahwa apabila motivasi, contohnya dari segi eksistensi yang ditunjukkan dari terpenuhinya kebutuhan dasar pegawai Kantor Kelurahan di Wilayah Kecamatan Mantikulore Kota Palu, mampu mendorong pegawai untuk lebih bekerja keras untuk mencapai hasil kerja yang diharapkan. Serta ditunjang dengan disiplin kerja yang baik contohnya dari segi disiplin administratif, pegawai Kantor Kelurahan di Wilayah Kecamatan Mantikulore Kota Palu patuh terhadap prosedurprosedur yang ditetapkan serta patuh dalam melaksanakan setiap tugas, yang mana hal tersebut akan berdampak pada peningkatan kinerja pegawai Kantor Kelurahan di Wilayah Kecamatan Mantikulore Kota Palu. 
Ningsi, S.W.

Berdasarkan penjelasan tersebut dapat dikatakan bahwa kedua variabel independen yaitu motivasi dan disiplin kerja memiliki pengaruh terhadap kinerja pegawai pada Kantor Kelurahan di Wilayah Kecamatan Mantikulore Kota Palu. Penelitian ini sejalan dengan hasil penelitian yang dilakukan oleh Kurdi (2014) menyatakan bahwa variabel disiplin kerja, motivasi dan lingkungan kerja secara bersama-sama mempunyai pengaruh positif dan signifikan terhadap kinerja Pegawai Negeri Sipil Kelurahan se Kecamatan Kota Kendal.

\section{Pengaruh Motivasi ( $\left.\mathbf{X}_{1}\right)$ Terhadap Kinerja (Y) Pegawai Kantor Kelurahan di Wilayah Kecamatan Mantikulore Kota Palu.}

Hasil pengujian hipotesis kedua $\left(\mathrm{H}_{2}\right)$ yaitu Uji-t menunjukkan bahwa variabel motivasi $\left(\mathrm{X}_{1}\right)$ berpengaruh positif dan signifikan terhadap kinerja pegawai pada Kantor Kelurahan di Wilayah Kecamatan Mantikulore Kota Palu. Hasil ini memberikan makna bahwa semakin tinggi tingkat kenaikan variabel motivasi yang diberikan, maka akan diikuti semakin meningkatnya kinerja pegawai. Menurut Hasibuan (2008:141) motivasi adalah hal yang menjadi penyebabkan, penyalurkan dan pendukung perilaku manusia atau individu agar mau bekerja dengan giat dan antusias demi mencapai hasil (kinerja) yang optimal.

Berdasarkan frekuensi tanggapan responden, mayoritas menyatakan bahwa motivasi masih dinilai positif dengan intreprestasi nilai rata-rata variabel motivasi termasuk dalam kategori baik, dimensi motivasi yang memiliki pengaruh paling tinggi terhadap kinerja pegawai adalah dimensi motivasi kebutuhan eksistensi atau kebutuhan akan bertahan hidup. hal ini dapat diartikan bahwa motivasi kebutuhan eksistensi merupakan dimensi yang paling berpengaruh dalam memotivasi pegawai untuk mampu menunjukan kemampuan kerja pegawai.

Hal ini menjelaskan bahwa mayoritas pegawai Kantor Kelurahan di Wilayah Kecamatan Mantikulore Kota Palu setuju bahwa dalam menciptakan kinerja yang baik, instansi perlu berupaya untuk dapat memenuhi kebutuhan dasar pegawainya baik secara rohani ataupun jasmani, apabila semua kebutuhan pegawai tersebut terpenuhi, maka akan ada semangat yang kuat yang dapat membangkitkan pegawai untuk bekerja.

Dimensi motivasi yang juga mengindikasikan kinerja pegawai adalah dimensi hubungan yang memengaruhi dari segi terpeliharanya hubungan komunikasi antar aparat di kelurahan dan dimensi pertumbuhan dari segi di diberikannya kesempatan bagi pegawai untuk mengembangkan potensi diri, kemampuan pegawai berkembang dengan bekerja di kantor kelurahan serta kepala kelurahan yang selalu mendorong pegawainya untuk mampu memberikan pendapat.Hasil penelitian ini sejalan dengan penelitian yang dilakukan oleh Sidanti (2015) dengan hasil penelitian bahwa variabel motivasi kerja secara parsial berpengaruh signifikan terhadap kinerja Pegawai Negeri Sipil Di Sekretariat DPRD Kabupaten Madiun.

\section{Pengaruh Disiplin Kerja $\left(\mathbf{X}_{2}\right)$ Terhadap Kinerja (Y) Pegawai Kantor Kelurahan di Wilayah Kecamatan Mantikulore Kota Palu.}

Berdasarkan hasil pengujian hipotesis ketiga $\left(\mathrm{H}_{3}\right)$ menunjukkan bahwa secara parsial variabel disiplin $\left(\mathrm{X}_{2}\right)$ terdapat pengaruh positif dan signifikan terhadap kinerja pegawai pada Kantor Kelurahan di Wilayah Kecamatan Mantikulore Kota Palu. Hal ini berarti, dengan adanya sikap kedisiplinan pegawai yang tinggi seperti kehadiran, ketepatan waktu masuk dan pulang kerja, ketaatan terhadap peraturan serta bertanggung jawab terhadap terhadap tugas yang dibebankan telah mampu memberi peningkatan terhadap kinerja pegawai. Bersamaan dengan tingginya tingkat kedisiplinan pegawai maka keberhasilan dalam pencapaian tujuan oleh kantor kelurahan juga akan semakin membaik. Hal ini berkaitan dengan teori disiplin kerja menurut Soejono (1986:65) menyatakan bahwa disiplin yang baik mencerminkan besarnya rasa tanggung jawab seseorang terhadap tugas-tugas yang diberikan kepadanya. Hal tersebut mendorong timbulya peningkatan kinerja serta tercapainya tujuan perusahaan, karyawan dan masyarakat, yang dalam hal ini organisasi, pegawai dan masyarakat. 
Berdasarkan frekuensi tanggapan responden, dimensi disiplin kerja yang memiliki pengaruh paling tinggi terhadap kinerja pegawai adalah dimensi disiplin administratif atau disiplin dengan melaksanakan pekerjaan sesuai prosedur yang ada, mengisi absen sesuai prosedurnya dan berpakaian sesuai aturan. Menurut Sastrohadiwiryo (2003:291) disiplin kerja dapat didefinisikan sebagai suatu sikap menghormati, menghargai, patuh dan taat terhadap peraturan-peraturan yang berlaku baik yang tertulis maupun tidak tertulis serta sanggup menjalankannya dan tidak mengelak untuk menerima sanksi-sanksinya apabila ia mlanggar tugas dan wewenang yang diberikan kepadanya. Hasil penelitian ini sejalan dengan penelitian yang dilakukan oleh Muliati (2014) dengan hasil penelitian bahwa variabel disiplin kerja secara parsial berpengaruh signifikan terhadap kinerja Pegawai Pada Dinas Bina Marga Propinsi Sulawesi Tengah.

\section{KESIMPULAN DAN SARAN}

\section{Kesimpulan}

1. Motivasi dan disiplin kerja secara simultan berpengaruh positif dan signifikan terhadap kinerja pegawai kantor kelurahan di wilayah Kecamatan Mantikulore Kota Palu.

2. Motivasi secara parsial berpengaruh positif dan signifikan terhadap kinerja pegawai Kantor Kelurahan di wilayah Kecamatan Mantikulore Kota Palu.

3. Disiplin kerja secara parsial berpengaruh positif dan signifikan terhadap kinerja pegawai Kantor Kelurahan di wilayah Kecamatan Mantikulore Kota Palu.

\section{Saran}

1. Variabel motivasi, perlu upaya untuk tetap mempertahankan, dan lebih memaksimalkan peningkatan motivasi kerja pegawai pada kantor kelurahan di wilayah Kecamatan Mantikulore Kota Palu, melalui pemberian kesempatan dan dorongan dari kepala kelurahan di wilayah Kecamatan Mantikulore Kota Palu, serta pemberian sarana dan prasarana/fasilitas bagi pegawai untuk mengembangkan kemampuan diri pegawai dalam hal teknologi, yang diharapkan dapat mampu meningkatkan kinerja pegawai pada Kantor Kelurahan Mantikulore Kota Palu.

2. Variabel disiplin, hendaknya kepala kelurahan di wilayah Kecamatan Mantikulore Kota Palu, untuk lebih meningkatkan rasa disiplin kerja pegawai kelurahan melalui, dengan mulai rutin mengaktifkan apel pagi dan apel pulang, dipertegasnya penerapan aturan-aturan tata tertib pada kantor kelurahan serta penerapan sanksi tegas bagi pegawai yang melanggar aturan dengan pemberian hukuman yang jelas dan sesuai dengan peraturan yang berlaku.

3. Variabel kinerja, hendaknya kepala kelurahan di wilayah Kecamatan Mantikulore Kota Palu, untuk senantiasa mendorong dan mengarahkan pegawainya agar mampu bertanggungjawab atas pekerjaan yang di berikan dan terciptanya sikap saling membantu antara pegawai kantor kelurahan dalam menyelesaikan pekerjaan. Serta melakukan evaluasi setiap hasil kerja pegawai oleh kepala kelurahan secara terus-menerus dan melakukan perbaikan terhadap hasil kerja dari pegawai kantor kelurahan.

\section{REFERENSI}

Bangun, Wilson. (2011). Intisari Manajemen, Bandung: PT Refika Aditama.

Dharma, Agus. (2003). Manajemen Supervisi. Jakarta: Raja Grafindo Persada.

Fahmi, Irham. (2010). Manajemen Kinerja, Bandung: Alfabet.

Hasibuan, Malayu, (2008). Manajemen Sumber Daya Manusia Edisi Revisi, Jakarta: PT. Gramedia Pustaka Umum.

Hasibuan, Malayu. (2013). Manajemen Sumber Daya Manusia, Cetakan Ketujuh Belas. Jakarta: Rajawali Pers. 


\section{Ningsi, S.W.}

Kurdi, Sulaiman. (2014). Pengaruh Disiplin Kerja, Motivasi dan Lingkungan Kerja Terhadap Kinerja Pegawai Negeri Sipil Kelurahan Se Kecamatan Kota Kendal. Jurnal Ekonomika dan Bisnis, Vol. 1, No.1, Hal 1-12.

Mangkunegara, A. A, Anwar Prabu. (2009). Evaluasi Kinerja Sumber Daya Manusia, Bandung: Refika Aditama.

Mas'ud, Fuad. (2004). Survai Diagnosis Organisasional : Konsep Dan Aplikasi, Semarang: Badan Penerbit Universitas Diponegoro.

Muliati (2014). Pengaruh Kompensasi, Disiplin Kerja Dan Lingkungan Kerja Terhadap Kinerja Pegawai Pada Dinas Bina Marga Propinsi Sulawesi Tengah. e-Jurnal Katalogis, Vol. 2, Nomor. 7, Hal 68-77.

Noor, Juliansyah. (2011). Metodologi Penelitian: Skripsi, Tesis, Disertasi, dan Karya Ilmiah, Jakarta: Kencana.

Rivai, Veitzhal. (2003). Manajemen Sumber Daya Manusia untuk Perusahaan: Dari Teori ke Praktik, Jakarta: PT. Raja Grafindo Persada.

Sastrohadiwiryo, Siswanto. (2003). Manajemen Tenaga Kerja Indonesia, Edisi Pertama, Cetakan Pertama, Jakarta: Bumi Aksara.

Siagian, Sondang P. (2004). Teori Motivasi dan Aplikasinya, Jakarta: PT. Rineka Cipta.

Sidanti, Heny. (2015). Pengaruh Lingkungan Kerja, Disiplin Kerja Dan Motivasi Kerja Terhadap Kinerja Pegawai Negeri Sipil Di Sekretariat DPRD Kabupaten Madiun. Jurnal JIBEKA Vol. 9, No. 1 , Hal $44-53$.

Soejono, Imam. (1986). Teknik Memimpin Pegawai Dan Pekerja, Jakarta: Jaya Sakti.

Soetrisno PH. (1992). Kapita selekta ekonomi Indonesia, Edisi Kedua, Yogyakarta: Penerbit Andi Offset.

Sugiyono. (2011). Metode Penelitian Administrasi dilengkapi dengan Metode R\&D, Bandung: Alfabeta.

Sugiyono. (2014). Metode Penelitian Bisnis, Bandung: Alfabeta.

Sutrisno, Edy. (2009). Manajemen Sumber Daya Manusia, Edisi Pertama, Cetakan Pertama, Jakarta: Prenada Media.

Taniredja, Tukiran dan Mustafidah. (2014). Penelitian Kuantitatif (Sebuah Pengantar), Bandung: CV. Alfabeta.

Undang-Undang Nomor 32 Tahun 2004, Tentang Pemerintahan Daerah.

Wibowo. (2007). Manajemen Kinerja, Edisi Kelima, Jakarta: PT. Raja Grafindo Persada. 